\title{
MINERAL RESOURCE POTENTIAL OF THE YOLLA BOLLY-MIDDLE EEI WILDERNESS AND ADJACENT ROADLESS AREAS, NORTHERN CALIFORNIA
}

\author{
SUMMARY REPORT
}

By

M. C. Blake, Jr., and A. S. Jayko

U.S. Geological Survey

and

A. M. Leszcykowski, W. D. Longwill, and Michael Gobla

U.S. Bureau of Mines

\section{STUDIES RELATED TO WILDERNESS}

Under the provisions of the Wilderness Act (Public Law 88-577, September 3, 1964) and related acts, the U.S. Geological Survey and the U.S. Bureau of Mines have been conducting mineral surveys of wilderness and primitive areas. Areas officially designated as "wilderness," "wild," or "canoe" when the act was passed were incorporated into the National Wilderness Preservation System, and some of them are presently being studied. The act provided that areas under consideration for wilderness designation should be studied for suitability for incorporation into the Wilderness System. The mineral surveys constitute one aspect of the suitability studies. The act directs that the results of such surveys are to be made available to the public and be submitted to the President and the Congress. This report discusses the results of a mineral survey of the Yolla Bolly-Middle Eel Wilderness and the Big Butte-Shinbone (5145), East Fork (5226), Murphy Glade (5298), and Wilderness Contiguous (5137) Roadless Areas, Shasta-Trinity, Six Rivers, and Mendocino National Forests, Tehama, Trinity, and Menducino Counties, California. The Yolla Bolly-Middle Eel Wilderness was established by Public Law 88-577, September 3, 1964. The roadless areas were classified as further planning areas during the Second Roadless Area Review and Evaluation (RARE II) by the U.S. Forest Service, January 1979.

\section{SUMMARY}

Mineral resources in the Yolla Bolly-Middle Eel Wilderness consist of two prospects containing 10,000 tons of inferred subeconomic manganese resources and 2.4 million tons of inferred subeconomic nickel resources. Twenty-one other prospects were investigated, but no resources potential was demonstrated.

All known resources within the four roadless areas adjacent to the Yolla Bolly-Middle Eel Wilderness in northern California occur in the Big Butte-Shinbone Roadless Area; they consist of an estimated 2,400 tons of subeconomic manganese resources averaging 9.5 percent $\mathrm{Mn}$, and 9,700 tons of subeconomic chromium (1.25 percent $\mathrm{Cr})$, nickel $(0.45$ percent $\mathrm{Ni})$, and cobalt $(0.03$ percent $\mathrm{Co}$ ) resources. Within the four additions, 62 mining claims have been located since 1910; none were patented. There are no Federal mineral leases within these areas. Potential for oil and gas, geothermal, and other mineral resources is low.

\section{INTRODUCTION}

The Yolla Bolly-Middle Eel Wilderness encompasses approximately 111,830 acres in Tehama and Trinity Counties in north-central California (fig. 1). The Big Butte-Shinbone (5145), East Fork (5226), Murphy Glade (5298), and Wilderness Contiguous (5137) Roadless Areas totaling 53,100 acres are within Shasta-Trinity, Six Rivers, and Mendocino National Forests. The areas lie in parts of Trinity, Tehama, and Mendocino Counties in northwestern California, about $80 \mathrm{mi}$ west of Red Bluff, Calif.; they are on the east edge of the Coast Ranges in the California Coast Ranges and Klamath Mountains geologic provinces.

Access to the wilderness and adjacent roadless areas from the east (Corning, a town $18 \mathrm{mi}$ south of Red Bluff on U.S. Interstate 5 ) is by county road and U.S. Forest Service roads (well marked) to the trailheads at Browns Camp and Ides Cove $(65 \mathrm{mi})$; from the north via Redding and California State Highway 36 to Harrison Gulch Ranger Station, then 22 mi southwest via U.S. Forest Service Road 28 N10 to Stuart Gap trailhead; from the southwest via Covelo and Eel River Ranger Station, thence by U.S. Forest Service Road approximately $27 \mathrm{mi}$ to Indian Dick trailhead.

Elevations range from approximately 2,700 to over $8,000 \mathrm{ft}$. The higher peaks include the North Yolla Bolly Mountains (double summit, 7,863 ft), Black Rock Mountain
$(7,755 \mathrm{ft})$, Hammerhorn Mountain $(7,567 \mathrm{ft})$, and the South Yolla Bolly Mountains $(8,083 \mathrm{ft})$. These peaks and other high points offer excellent views of other parts of the Coast Ranges, Klamath Mountains, Sacramento Valley, and the Sierra Nevada. Annual precipitation yaries from 35 to 60 in., with most being snow at the higher elevations. Snow depths may reach many feet on northerly slopes and often last well into July. Temperatures during periods of normal use (MayNovember) are generally moderate though extremes can range from $20^{\circ}$ to $90^{\circ} \mathrm{F}$

Timber types include mixed conifers of the Coast Range, pure fir types of the subalpine areas and mixed conifer and hardwoods. Other cover types include grasslands (commonly called "glades" locally), meadows (wet and dry), oak woodlands, and chamise chaparral (brush). Botanically, there are hundreds of species of plants.

\section{GEOLOGY, GEOCHEMISTRY, AND GEOPHYSICS PERTAINING TO MINERAL RESOURCE ASSESSMENT}

All of the rocks in the study area are assigned to the Franciscan assemblage of Mesozoic age. We have subdivided this assemblage into three tectonostratigraphic terranes based on lithology, age, structure, and metamorphic history; the Pickett Peak, Central, and Yolla Bolly.

The Pickett Peak terrane consists of quartz-mica 
schist, metagraywacke and minor basalt. The Central terrane is a tectonic melange characterized by large blocks of resistant basalt, chert, and sandstone in a highly sheared shaly matrix. Geologic mapping and geochemical sampling within the study area suggest that there are no mineralized zones in these terranes.

Geologic mapping and geochemical sampling (Blake and Jayko, 1983a, b) have established that all the mineralized areas are within the Yolla Bolly terrane of the Franciscan assemblage. The Yolla Bolly terrane is characterized by remarkably continuous interbeds of radiolarian chert in graywacke and shale. Most of the deposits are pods and lenses containing manganese minerals within the chert. Our field observations and geochemical analyses suggest that the manganese deposits were formed by hydrothermal alteration of the chert during intrusion of diabase-gabbro sills. The hydrothermal solutions apparently remobilized and concentrated the primary manganese in the unaltered chert (typically $400-2,000 \mathrm{ppm} \mathrm{Mn}$ ) to values as high as 43 percent $\mathrm{Mn}$ in mineralized zones adjacent to the intrusive sills.

A second group of deposits is associated with serpentinized ultramafic rocks tectonically injected into sedimentary rocks of the Yolla Bolly terrane. These deposits include primary chromite lenses in the least altered bodies, such as Red Mountain, and lateritic chromium, nickel, and cobalt concentrations (due to weathering) in serpentine. The latter group is visible as the small positive anomalies on the aeromagnetic map (U.S. Geological Survey, 1979).

A third group of deposits consists of quartz segregations and minor pyrite in metagraywacke and mica schist. None of the analyses of these rocks showed any anomalous values.

\section{MINING DISTRICTS AND MINERALIZATION}

Most mineralized areas and those with past mining activity are within the Big Butte-Shinbone Roadless Area and the Yolla Bolly Wilderness. No mineral resources are known in the East Fork, Murphy Glade, or Wilderness Contiguous Roadless Areas.

Although the study area was prospected and claims staked in the region as early as 1899 , no mining occurred until World War I, when a few tons of chromite-bearing rock were mined and stockpiled at the Grubstake prospect. Mining activity was renewed during World War II with the discovery of the Blue Jay manganese deposit in 1941; production from the mine continued intermittently through the Korean War period. Several other deposits outside the study area were also discovered and mined in the 1940's and 1950's. Mining activity took place during national emergencies, when premium prices were paid for such strategic minerals as manganese and chromite. Manganese production from the region ceased with the closing of the Blue Jay mine in 1956. There has been no subsequent mining activity in the area.

The accompanying map shows the locations of mines and prospects in and near the Yolla Bolly-Middle Eel Wilderness and adjacent roadless areas. The U.S. Bureau of Land Management master title plats indicate no patented claims, Federal mineral leases, or mineral-material sites in the study area.

\section{Yolla Bolly-Middle Eel Wilderness}

Two localities in the study area have a low mineral resource potential-a manganese occurrence near Bearwallow (Bertha group) and a nickel occurrence on Wrights Ridge. Figure 2 shows the locations of the nickel- and manganesebearing areas in the study area.

Manganese at Bearwallow (Bertha group) occurs as pods and lenses in chert beds of the Yolla Bolly terrane. The manganese minerals were derived from hydrothermal solutions associated with diabase intrusions along fractures. The pods and host rocks trend $\mathrm{N} .70^{\circ} \mathrm{W}$. and dip $60^{\circ} \mathrm{NE}$. Psilomelane- and pyrolusite-bearing material contains as much as 39.2 percent $\mathrm{Mn}$ (avg. 21 percent) and 0.56 percent Fe. The pods occur in two zones along strike: Pods in the eastern zone average $1.5 \mathrm{ft}$ in thickness and are 45 to $75 \mathrm{ft}$ long; one pod in the western zone is $10 \mathrm{ft}$ thick and $40 \mathrm{ft}$ long. Approximately 10,000 tons of inferred subeconomic resources is estimated in the pods exposed on the surface.

Nickel at Wrights Ridge occurs in serpentinized ultramafic bodies that have been tectonically emplaced into sedimentary rocks of the Yolla Bolly terrane. Two samples from across an outcrop of serpentinized ultramafic rock, visible on the surface for $400 \mathrm{ft}$, contained 0.98 and 1.00 percent Ni. Approximately 2.4 million tons of inferred subeconomic resources is estimated in this area.

Two other areas of old claims were investigated during the present study. The Tomhead mine, located outside the wilderness near Tomhead Mountain (fig. 1), consists of pyrite veins and pods in the South Fork Mountain Schist. Several other nearby claims are in metamorphic quartz segregations in mica schist. None of the samples analyzed from these prospects gave anomalous values. The other group of claims, located east of the South Yolla Bolly Mountains (fig. 1), consists of metamorphic quartz veins in metagraywacke. These samples were also devoid of any anomalous values.

\section{Big Butte-Shinbone Roadless Area}

The Big Butte-Shinbone Roadless Area, encompassing 35,300 acres, lies west and south of the Yolla Bolly-Middle Eel Wilderness. Deposits of manganese, chromite, asbestos, and jade represent the only minerals of potential resource.

The Blue Jay manganese mine (fig. 2) produced more then 4,600 tons of ore averaging 50 percent Mn between 1942 and 1956 (Trask, 1950, p. 309-310; Trengove, 1960, p. 16). The main ore mineral was hausmannite, a primary reddishbrown manganese oxide, which occurred in two flat elliptical lenses in chert about $4 \mathrm{ft}$ thick and $15 \mathrm{ft}$ apart; the upper lens measured about $200 \mathrm{ft}$ along strike, and the lower one 400 ft. Early production was from underground adits; later, the lenses were stripped of overburden and mined by open pit. The mine was abandoned in 1956 after exploration work proved unsuccessful. About 2,400 tons of indicated and inferred subeconomic resources averaging 9.5 percent $\mathrm{Mn}$ remains at the mine. Additional manganese resources of similar grade probably occur nearby downdip along chert beds.

The Trout Creek mine (fig. 2), about half a mile outside the study-area boundary, produced more than 1,000 tons of manganese ore (Trengove, 1960, p. 18). The Lucky Sunday mine (fig. 2), several miles to the north, produced 260 tons of manganese ore (O'Brien, 1965, p. 117). Other deposits in the vicinity have been prospected, some of which may have produced small unrecorded amounts.

During World War I, about 20 tons of chromite-rich ultramafic rock was mined and stockpiled at the Grubstake prospect (fig. 2). Subsequent exploration exposed a narrow zone, about $80 \mathrm{ft}$ long, containing sporadic pods of chromitebearing rock. To the west is a flat area, about $400 \mathrm{ft}$ wide and $600 \mathrm{ft}$ long, covered with red laterite soil derived from serpentine; the soil averages about $0.7 \mathrm{ft}$ in thickness. About 40 tons of indicated subeconomic resources containing about 2.5 percent chromium oxide $\left(\mathrm{Cr}_{2} \mathrm{O}_{3}\right), 0.26$ percent $\mathrm{Ni}$ and 0.01 troy oz Au per ton is exposed at the Grubstake prospect; 5 tons of nearby stockpiled rock averages about 31 percent $\mathrm{Cr}_{2} \mathrm{O}_{3}$. In addition, the laterite soil contains about 9,700 tons of subeconomic resources averaging 1.25 percent $\mathrm{Cr}_{2} \mathrm{O}_{3}, 0.45$ percent $\mathrm{Ni}$, and $\mathbf{0 . 0 3}$ percent $\mathrm{Co}$.

Chrysotile asbestos veinlets occur in widely scattered zones throughout the ultramafic sill-like mass south of Red Mountain. No resources were identified.

Several small jade occurrences lie within the roadless area. However, prospecting appears to have been unsuccessful.

\section{East Fork Roadless Area}

The East Fork Roadless Area, which lies at the north end of the Yolla Bolly-Middle Eel Wilderness, encompasses 6,200 acres. There has been no production of minerals within the area. The only claims found were a group of five claims located along a zone of sporadic pods of metachert within the Franciscan rocks east of Black Rock Mountain (fig. 1). Some of these pods contain minor amounts of manganese. Prospect 
workings consist of one shallow pit.

The East Fork Roadless Area is considered to have a very low mineral resource potential.

\section{Murphy Glade Roadless Area}

The Murphy Glade Roadless Area, encompassing 900 acres lies just to the east of the East Fork Roadless Area. There has been no mineral production within the area, and no claims or mineralized areas were found. Mineral resource potential is low.

\section{Wilderness Contiguous Roadless Area}

The Wilderness Contiguous Roadless Area consists of two separate parcels, totaling 10,700 acres in area, at the south end of the Yolla Bolly-Middle Eel Wilderness. No mineralized areas, mines, or prospects were found, and no mineral resources are known to occur in the roadless area.

\section{ASSESSMENT OF MINERAL RESOURCE POTENTIAL}

The mineral resource potential (fig. 2) for manganese and nickel in the Yolla Bolly-Middle Eel Wilderness is low. Although resources were calculated for both commodities, these resources are submarginal because of limited tonnages, remoteness, absence of water, and distance from processing facilities.

No localities with mineral resource potential are known in the East Fork, Murphy Glade, or Wilderness Contiguous Roadless Areas. All known and potential resources within the roadless areas occur in the Big ButteShinbone Roedless Aree. Resources within this roadless aree include manganese at the Blue Jay mine and chromite at the Grubstake prospect. Although there may be additional occur rences of similar grade nearby, the mineral resource potential is low because of small tonnages and low grades. Extension of known deposits would probably be deeper with greater thickness of overburden.

\section{REPERENCES CITED}

Blake, M. C., Jr., and Jayko, A. S., 1983a, Geochemical map of the Yolla Bolly-Middle Eel Wilderness and adjacent roadless areas, northern California: U.S. Geological Survey Miscellaneous Field Studies Map MF-1595-C [in press .

_- 1983b, Preliminary geologic map of the Yolla BollyMiddle Eel Wilderness and adjacent roadless areas, northern California: U.S. Geological Survey Miscellaneous Field Studies Map MF-1595-A, scale 1,62,500.

O'Brien, J. C., 1965, Mines and mineral resources of Trinity County, California: California Division of Mines and Geology County Report 4, 125 p.

Trask, P. D., 1950, Geologic description of the manganese deposits of California: California Division of Mines and Geology Bulletin 152, $378 \mathrm{p}$.

Trengove, R. R., 1960, Reconnaissance of California manganese deposits: U.S. Bureau of Mines Report of Investigation $5579,46 \mathrm{p}$.

U.S. Geological Survey, 1979, Aeromagnetic map of the Yolla Bolly area, California: U.S. Geological Survey OpenFile Report 79-1196, scale 1:62,500.

Wells, F. G., and Hawkes, H. E., 1965, Chromite deposits of Shasta, Tehama, Trinity, and Humboldt Counties, California, chap. 3 of Klamath Mountains, pt. 1 of Geological investigations of chromite in California: California Division of Mines and Geology Bulletin 134 p. 130-191. 


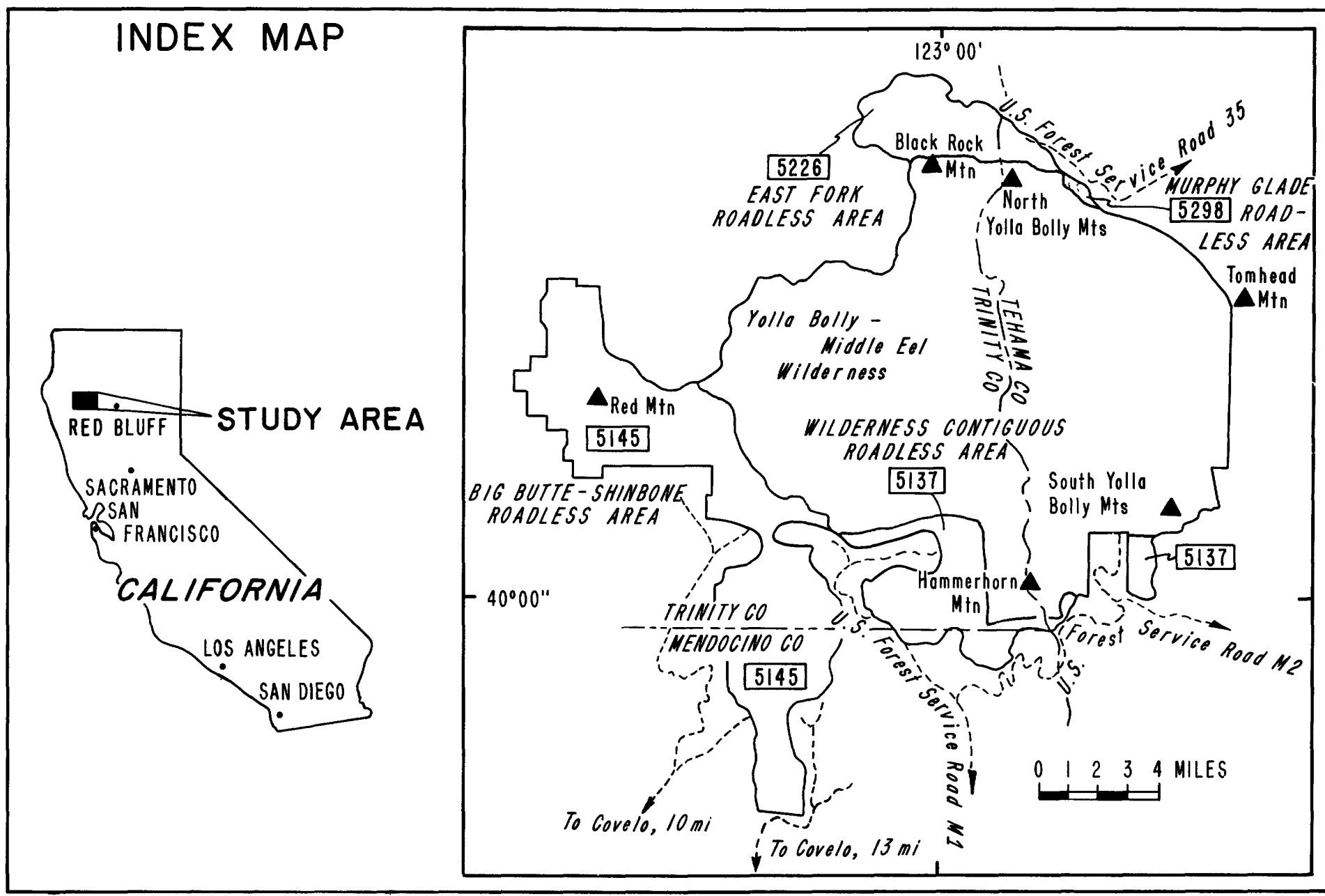

Figure 1.-Index map of study area, showing locations of Yolla Bolly-Middle Eel Wilderness and adjacent roadless areas, northern California. 


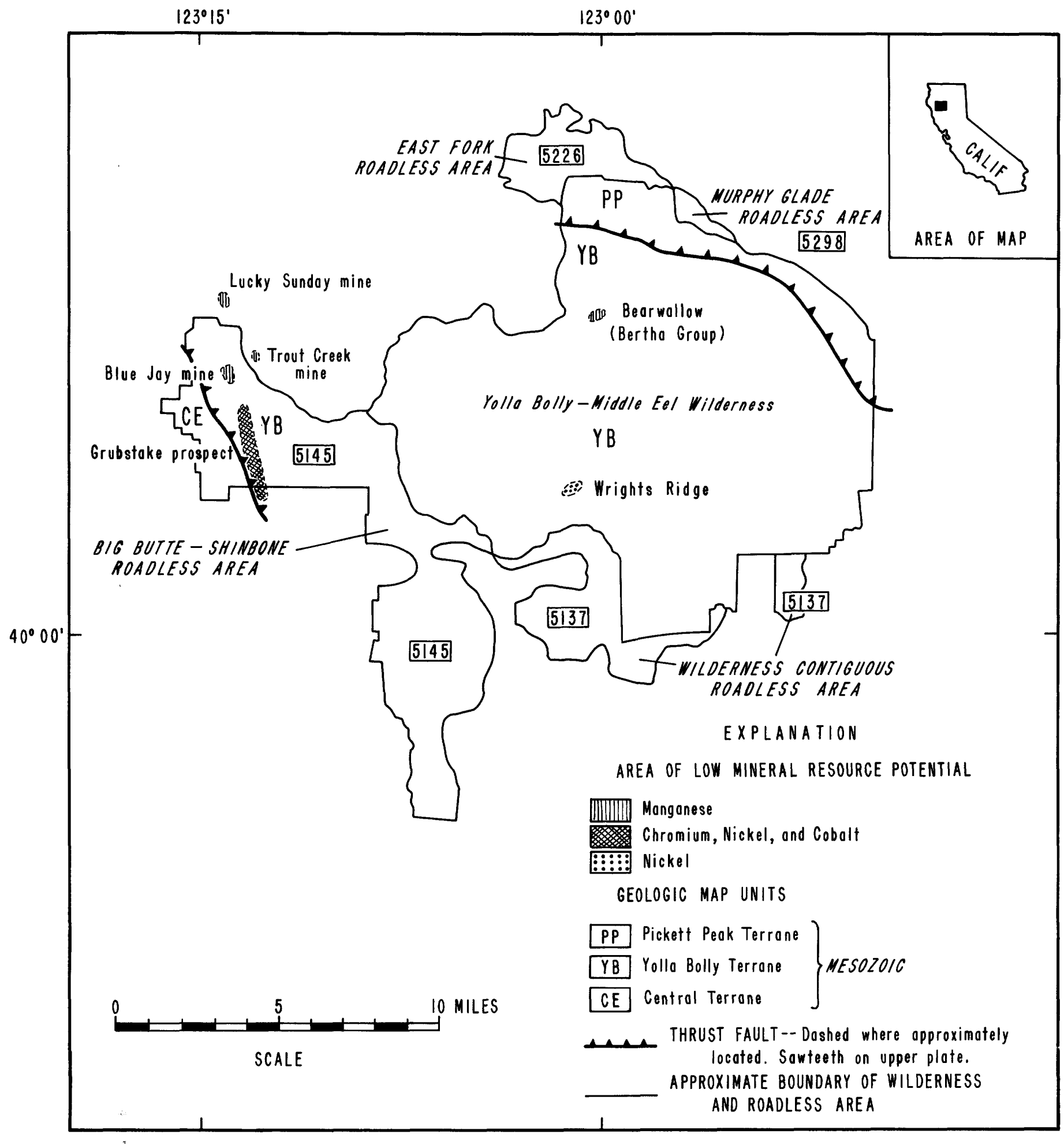

Figure 2.--Areas of mineral resource potential in the study area. 


$$
\dot{*}
$$

